has succeeded Mr. J. Newby, of the Imperial College of Science and 'Technology, as general secretary, and the report includes a warm tribute to Mr. Newby's work. The annual conference in 1957 will take place in Aachen, January 14-17.

\section{Industrial Information Overseas}

UNDER the title "Telling Industry's Story Overseas" (pp, iv $+61 ; 3 s .6 d$.$) , the Publicity Committee$ of the F'ederation of British Industries has issued a guide to the channels available for distributing industrial information overseas. The first chapter describes the final outlets-newspapers, magazines, periodicals, broadcasting agencies, films-through which a story can reach the public, or a particular section of the public, in overseas markets. In the second chapter the various channels of communication through which a story can be distributed and fed into these final outlets are described, while in the third, practical hints are given on how to use these channels. Appendixes list journals published in Great Britain mainly or exclusively for overseas ; B.B.C. external regional services; world television services; and the names and addresses of the Central Office of Information's Chief Regional Officers.

\section{"British Rainfall, 1954"}

1954 was the wettest year over Great Britain as a whole since 1903. Over a large part of the country the fall was 140 per cent of the average. This was due not so much to the wet summer as to the fact that an unusually rainy summer was followed by an even more unusually rainy autumn. 'Though the summer rain impressed the public more, probably, than that of the autumn, it was by no means record. breaking. In both 1912 and 1879 nearly half as much rain again (15.9 and 15.7 in., respectively) fell in the three months June to August as fell in 1954 (11.6 in.). The 1954 average for the whole country was $39 \cdot 1 \mathrm{in}$. compared with a normal (1881-1915) of $32 \cdot 67$ in. Only the Thames Estuary, by a few per cent, had less than the normal. The nature of the summer of 1954, with its succession of major depressions giving long periods of continuous moderate rain, is reflected in the comparative absence of heavy falls in short periods associated with thunderstorms. April 1954 was an exceedingly dry month, in which two stations in Devonshire had only $0.01 \mathrm{in}$., and the fall was less than 25 per cent over much of the country. Among other information in "British Rainfall, 1954" (Meteorological Office, London: H.M. Stationery Office, 1956. 25s. net) we learn that the organization of instruments for the recording ats Cardington, Bedford, of rainfall variations over a small area reached an advanced stage. In this work, sixteen synchronized recording rain-gauges distributed over an area of four square miles will provide a detailed and accurate analysis of the spatial distribution of heavy falls of rain which will be of especial value in the design of surface water drainage systems as well as being of general meteorological intorest.

\section{International Committee for Bird Preservation}

THE first meeting of the International Committee for Bird Preservation to take place in the continent of Africa will be in Bulawayo this year, when the Central and South African Conference will be held during July 8-11, followed by an excursion through the Wankie Game Reserve. Inquiries should be addressed to the secretary, Miss P. Barclay-Smith, British Museum (Natural History), London, S.W.7.
The Federation of Rhodesia and Nyaseland is the latest country to form a National Section of the International Committee for Bird Preservation, thereby bringing the total up to forty-five. The membership of the National Section of Rhodesia and Nyasaland is composed of the National Museums of Southern Rhodesia, the Department of National Parks, Game and Tsetse Control Department, Natural Resources Board, Natural and Historical Monuments Commission, Southern Rhodesia Game Department, National Hunters and Game Preservation Association and the Rhodesian Ornithological Society.

\section{Forest Research in Canada}

THE recognition in Canada of the great destruction of its forests and the wasteful utilization, with the realization that the forests were not inexhaustible, has resulted in a great swing towards conservation with a growing interest in forestry research in all its branches. In a recent publication of the Forestry Branch of the Department of Northern Affairs and National Resources, entitled "Research Work of the Forestry Branch" (Misc. Pub. No. 6; Ottawa, 1956), it is stated that research into the many phases of forestry and forest utilization is now carried out by a number of governmental, university and industrial agencies within a fairly definite pattern and with little duplication of effort; the latter a most important point. This is an important small publication, since it deals with both the forests and forest research situations in Canada and the organization of the Forestry Branch. It outlines the history of forest research and organization of the Research Division and its functions, and of forest policy. Forest products research is dealt with separately as this has more specially reference to industrial requirements. Finally, forest economics are glanced at.

\section{Forest Products Statistics of the World}

THE ninth "Year Book of Forest Products Statistics", prepared by the Forestry Division of the United Nations Food and Agriculture Organization, contains information gathered from more than a hundred and twenty countries for 1954, together with revised data for 1953. The tenth anniversary of the Organization occurred last year, and the work of the decade has been devoted to improving the standard of international forestry and forest products statistics. The latest year book is more complete and accurate for more countries than its predecessors. Good statistical information is considered to be the base of good forestry, and programmes for this purpose are being started and improved under the auspices of the Organization.

\section{Films on Parasitology}

AT a congress of the International Scientific Film Association which met in Brussels in 1949, it was decided to collect information about films dealing with human and comparative parasitology. The work was begun by Prof. Rodolfo V. Talice of the University of the Eastern Republic of Uruguay and was later published. A third edition of the list of films has now been published and contains information about 260 films from nineteen countries. Britain is well represented; but, not surprisingly, the United States contributes more than any other country; the number from the U.S.S.R. is disappointingly few. The films are grouped under the heading of general 